\title{
Comorbidity as an independent prognostic factor in elderly patients with peripheral T-cell lymphoma
}

This article was published in the following Dove Press journal:

OncoTargets and Therapy

24 March 2016

Number of times this article has been viewed

\author{
Haifeng Zhaol,* \\ Tengteng Wangl,* \\ Yafei Wang' \\ Yong Yu' \\ Xiaofan Wang' \\ Zhigang Zhao' \\ Hongliang Yang' \\ Bei Yan ${ }^{2}$ \\ Xiaoxiong $\mathrm{Wu}^{2}$ \\ Wanming $\mathrm{Da}^{3}$ \\ Yizhuo Zhangl,* \\ 'Department of Hematology, Tianjin \\ Medical University Cancer Institute \\ and Hospital, National Clinical \\ Research Center for Cancer, Key \\ Laboratory of Cancer Prevention \\ and Therapy, Tianjin, ${ }^{2}$ Department of \\ Hematology, First Affiliated Hospital \\ of Chinese People's Liberation Army \\ General Hospital, ${ }^{3}$ Department \\ of Hematology, Chinese People's \\ Liberation Army General Hospital, \\ Beijing, People's Republic of China \\ *These authors contributed equally \\ to this work
}

Correspondence: Yizhuo Zhang Department of Hematology, Tianjin Medical University Cancer Institute and Hospital, National Clinical Research Center for Cancer, Key Laboratory of Cancer Prevention and Therapy, Tianjin 300060, People's Republic of China

Tel +8622 23359337

Fax +8622 23359337

Email yizhuozhangIII@I63.com

\begin{abstract}
The aim of the present study was to investigate the role of comorbidities in the outcomes of patients with peripheral T-cell lymphoma (PTCL) in a Chinese population. Fifty-six newly diagnosed PTCL patients aged $>60$ years were enrolled in our institution between April 2008 and August 2014. Medical record details including clinical parameters, pathological status, and treatment were reviewed. Prognostic factors were assessed using univariate and multivariate analyses. Forty-one (73.2\%) patients with PTCL, not otherwise specified (PTCL-NOS), nine (16.1\%) with angioimmunoblastic T-cell lymphoma, and six (10.7\%) with anaplastic large cell lymphoma were recruited in this study. Twenty-eight (50\%) had at least one comorbidity. Univariate analysis showed that an Eastern Cooperative Oncology Group score of 2-4, the presence of B symptoms, an International Prognostic Index (IPI) score of 3-5, and a Charlson Comorbidity Index (CCI) score $\geq 2$ were significantly associated with shortened overall survival (OS), whereas the presence of B symptoms, an IPI of 3-5, and a CCI $\geq 2$ were associated with worsened progression-free survival (PFS). Multivariate analysis indicated that a high CCI $(\geq 2)$ and a high IPI (3-5) were poor independent prognostic factors for OS and PFS in the elderly patients with PTCL. Comorbidity was identified as a new independent poor prognostic factor for elderly patients with PTCL.
\end{abstract}

Keywords: comorbidity, peripheral T-cell lymphoma, OS, PFS, prognostic factor

\section{Introduction}

Peripheral T-cell lymphoma (PTCL) is a heterogeneous group of non-Hodgkin's lymphomas with the characteristics of rare incidence, aggressive course, and poor survival. ${ }^{1}$ PTCL, not otherwise specified (PTCL-NOS), angioimmunoblastic T-cell lymphoma (AITL), and anaplastic large cell lymphoma (ALCL) are the major PTCL subtypes in Asia, representing $\sim 40 \%$ of cases. ${ }^{2}$ The cyclophosphamide, adriamycin, vincristine, and prednisone (CHOP) regimen is widely used as a first-line treatment for PTCL, but the outcomes are very poor with a 5-year overall survival (OS) rate of $\sim 30 \%{ }^{1}$

With the increase in life expectancy, increasingly more patients with PTCL are $>60$ years of age, and those patients always have one or more comorbidities such as diabetes or cerebrovascular disease, which not only influence the prognosis of the disease itself but may also affect the treatment choice. ${ }^{3-5}$ Therefore, a single numeric score of comorbidity, based on the collection of several comorbidities, was a very useful and important method, which can reduce the number of candidate variables into a manageable set of proxy variables. ${ }^{6,7}$ The Charlson Comorbidity Index (CCI) is the most widely used comorbidity index. ${ }^{5,8}$

An analysis to determine whether the CCI can predict the survival of elderly patients with PTCL has not yet been performed. It was reported that the CCI is a useful index 
to predict outcomes in nonhematologic $\mathrm{c}^{9-11}$ and hematologic malignancies. ${ }^{12-14}$ Therefore, this retrospective study analyzed patients' clinical parameters and treatment outcomes to determine the impact of CCI on elderly patients with PTCL.

\section{Materials and methods}

\section{Patient selection}

In this study, 56 patients aged $>60$ years with newly diagnosed PTCL were recruited between April 2008 and August 2014. The last follow-up date was March 31, 2015. According to the World Health Organization classification, ${ }^{15}$ the PTCL-NOS, ALCL, and AITL subtypes were included in this study. The study was approved by the Research Ethics Committee of Tianjin Cancer Hospital, People's Republic of China. Written informed consent was obtained from the patients prior to their participation.

\section{Data collection}

The patients' medical records were reviewed for their clinical, pathological, and treatment data. Each patient's history; performance status; blood routine; liver function; renal function; lactate dehydrogenase (LDH); computed tomography scans of the thorax, abdomen, and pelvic cavity; bone marrow aspiration and biopsy; and cognitive status were documented. International Prognostic Index (IPI) scores were based on age, Eastern Cooperative Oncology Group (ECOG) performance status, LDH concentrations, number of extranodal sites involved, and Ann Arbor stage. The treatment responses were classified as complete remission (CR), partial response (PR), stable disease (SD), or progressive disease (PD) according to the International Working Group criteria. ${ }^{16}$ In this study, hemoglobin $<120 \mathrm{~g} / \mathrm{L}$ was defined as low, LDH $>245 \mathrm{U} / \mathrm{L}$ was defined as high, and $\beta$-microglobulin $(\beta 2-\mathrm{MG})>2.2 \mathrm{mg} / \mathrm{L}$ was defined as high. The CCI score of each patient was calculated according to their past and present medical history. ${ }^{8,17}$

\section{Statistical analysis}

A statistical analysis was performed using SPSS 19.0 software (SPSS Inc., Chicago, IL, USA). OS was calculated from the diagnosis until death from any cause, while progressionfree survival (PFS) was calculated from the diagnosis until disease progression or death. The survival curve was calculated by the log-rank test. Multivariate analysis was performed using the Cox proportional hazards regression model. The GraphPad Prism software package was used to create the Kaplan-Meier estimate graphs. Values of $P<0.05$ were considered statistically significant.

\section{Results \\ Patient characteristics}

A total of 34 males (60.7\%) and 22 females (39.3\%) with a median age of 67 years (range: $60-80$ years) were included in this study. With regard to histological subtypes, 41 (73.2\%) patients had PTCL-NOS, nine (16.1\%) had AITL, and six $(10.7 \%)$ had ALCL. All of the patients were divided into the low CCI (score 0 or 1 ) and high CCI (score $\geq 2$ ) groups. Thirteen patients were included in the high CCI group. The patients' clinical parameters and histological features are summarized in Table 1.

Table I Clinical characteristics of patients with PTCL

\begin{tabular}{|c|c|}
\hline Characteristic & $\begin{array}{l}\text { No of } \\
\text { patients (\%) }\end{array}$ \\
\hline \multicolumn{2}{|l|}{ Sex } \\
\hline Male & $34(60.7)$ \\
\hline Female & $22(39.3)$ \\
\hline \multicolumn{2}{|l|}{ Age (years) } \\
\hline$\leq 70$ & $38(67.9)$ \\
\hline$>70$ & $18(32.1)$ \\
\hline \multicolumn{2}{|c|}{ Performance status } \\
\hline ECOG 0-I & $32(57.1)$ \\
\hline ECOG 2-4 & $24(42.9)$ \\
\hline \multicolumn{2}{|l|}{ Pathological type } \\
\hline PTCL-NOS & $4 \mid(73.2)$ \\
\hline AITL & $9(16.1)$ \\
\hline $\mathrm{ALCL}$ & $6(10.7)$ \\
\hline \multicolumn{2}{|l|}{ LDH } \\
\hline Normal & $21(37.5)$ \\
\hline Elevated & $35(62.5)$ \\
\hline \multicolumn{2}{|l|}{ Hemoglobin } \\
\hline Normal & $43(76.8)$ \\
\hline Low & $13(23.2)$ \\
\hline \multicolumn{2}{|l|}{ B symptoms } \\
\hline Present & $23(4 I . I)$ \\
\hline Absent & $33(58.9)$ \\
\hline \multicolumn{2}{|l|}{$\beta 2-M G$} \\
\hline Normal & $34(60.7)$ \\
\hline Elevated & $22(39.3)$ \\
\hline \multicolumn{2}{|c|}{ Bone marrow involvement } \\
\hline Yes & $4(7.0)$ \\
\hline No & $52(93.0)$ \\
\hline \multicolumn{2}{|l|}{ Ann Arbor stage } \\
\hline $\mathrm{I} / \mathrm{II}$ & $17(30.4)$ \\
\hline $\mathrm{III} / \mathrm{IV}$ & $39(69.6)$ \\
\hline \multicolumn{2}{|l|}{ IPI } \\
\hline $\mathrm{I}-2$ & $20(35.7)$ \\
\hline $3-5$ & $36(64.3)$ \\
\hline \multicolumn{2}{|l|}{$\mathrm{CCl}$} \\
\hline 0 & $28(50.0)$ \\
\hline I & $15(26.8)$ \\
\hline 2 & $6(10.7)$ \\
\hline$>2$ & $7(12.5)$ \\
\hline
\end{tabular}


Table I (Continued)

\begin{tabular}{ll}
\hline Characteristic & $\begin{array}{l}\text { No of } \\
\text { patients (\%) }\end{array}$ \\
\hline Treatment & \\
CHOP/CHOP-like regimen & $45(80.4)$ \\
Regimen other than CHOP & II (19.6) \\
Therapeutic evaluation & \\
CR/PR & $34(60.7)$ \\
SD/PD & $22(39.3)$ \\
\hline
\end{tabular}

Abbreviations: PTCL-NOS, peripheral T-cell lymphoma, not otherwise specified; ALCL, anaplastic large cell lymphoma; AITL, angioimmunoblastic T-cell lymphoma; ECOG, Eastern Cooperative Oncology Group; LDH, lactate dehydrogenase; $32-M G$, $\beta$-microglobulin; CHOP, combination chemotherapy with cyclophosphamide, doxorubicin, vincristine, and prednisone; IPI, International Prognostic Index; CR, complete remission; PR, partial remission; SD, stable disease; PD, progressive disease; $\mathrm{CCl}$, Charlson Comorbidity Index.

Twenty-eight (50\%) patients had at least one comorbidity, the most common of which were diabetes and cerebrovascular disease (Table 2). Most patients were treated with CHOP or CHOP-like regimen as the first-line treatment, while six patients were treated with modified cyclophosphamide, doxorubicin, vincristine, and dexamethasone (HyperCVAD) and five were treated with another regimen. Thirty-four patients (60.7\%) achieved CR or PR at the end of the treatment, while 22 patients (39.3\%) had SD or PD.

\section{Prognostic factor analysis}

Each patient's medical records were retrospectively reviewed. The patients were divided into two subgroups according to

Table 2 Charlson Comorbidity Index of patients with PTCL

\begin{tabular}{lll}
\hline Characteristic & Score & $\begin{array}{l}\text { No of } \\
\text { patients }\end{array}$ \\
\hline Myocardial infarction & I & 2 \\
Congestive heart failure & $\mathrm{I}$ & $\mathrm{I}$ \\
Peripheral vascular disease & $\mathrm{I}$ & $\mathrm{I}$ \\
Cerebrovascular disease (except & $\mathrm{I}$ & 7 \\
hemiplegia) & $\mathrm{I}$ & $\mathrm{I}$ \\
Dementia & $\mathrm{I}$ & $\mathrm{I}$ \\
Chronic pulmonary disease & $\mathrm{I}$ & 2 \\
Connective tissue disease & $\mathrm{I}$ & 3 \\
Ulcer disease & $\mathrm{I}$ & $\mathrm{I}$ \\
Mild liver disease & $\mathrm{I}$ & 12 \\
Diabetes without complications & 2 & $\mathrm{I}$ \\
Diabetes with end-organ damage & 2 & 1 \\
Hemiplegia & 2 & 0 \\
Moderate or severe renal disease & 2 & 0 \\
Second solid tumor (nonmetastatic) & 2 & 0 \\
Leukemia & 2 & 0 \\
Lymphoma* & 3 & 1 \\
Moderate or severe liver disease & 6 & 0 \\
Second metastatic solid tumor & 6 & 0 \\
Acquired immunodeficiency syndrome &
\end{tabular}

Note: *Excluded from analysis.

Abbreviation: PTCL, peripheral T-cell lymphoma. age ( $\leq 70$ vs $>70$ years), sex (male vs female), ECOG score (0-1 vs 2-4), hemoglobin (normal vs low), B symptoms (present vs absent), Ann Arbor stage (I-II vs III-IV), $\beta 2-\mathrm{MG}$ (normal vs elevated), bone marrow involvement (positive vs negative), LDH concentrations (normal vs elevated), IPI ( $1-2$ vs $3-5)$, and CCI $(0-1$ vs $\geq 2)$.

Univariate analysis showed that an ECOG score of 2-4, the presence of B symptoms, an IPI of 3-5, and a CCI $\geq 2$ were significantly associated with worse OS, while the presence of B symptoms, an IPI of 3-5, and a CCI $\geq 2$ were associated with shortened PFS. Multivariate analysis indicated that a high CCI and a high IPI were poor independent prognostic factors for patients with PTCL (Tables 3 and 4). OS and PFS in the high CCI group were significantly shorter than those in the low CCI group $(P=0.0085$ and $P=0.0028$, respectively; Figure 1).

\section{Discussion}

PTCL encompasses a subset of rare and usually aggressive T-cell diseases that account for $\sim 12 \%$ of cases of nonHodgkin lymphomas in Western countries. ${ }^{18}$ However, in Asia, the incidence was higher, $>20 \% .{ }^{19,20}$ Due to its rarity and lack of standardized treatment strategies, its prognosis remains very poor.

The CCI is the most commonly applied comorbidity score system, and a high CCI represents shortened survival. ${ }^{11,21}$ It had been shown that the comorbidity can be regarded as an independent risk factor in several solid and hematological malignancies. ${ }^{10,22,23}$ Studies on the impact of comorbidity on survival in B-cell non-Hodgkin lymphoma revealed that a high CCI was associated with poor OS..$^{13,24,25}$

Until now, there have been no data on the ability of the CCI to predict survival in elderly patients with PTCL in a Chinese population. The purpose of this study was to assess comorbidity to evaluate survival among patients with PTCL treated with $\mathrm{CHOP}$ or CHOP-like regimen. Univariate analysis showed that the presence of B symptoms, an IPI of $3-5$, and a CCI $\geq 2$ were significantly associated with shortened OS and PFS. Multivariate analysis findings suggested that a high CCI was an independent poor risk factor for elderly patients with PTCL.

\section{Conclusion}

Comorbidity was considered a poor independent prognostic factor for shortened OS and PFS in patients with PTCL treated with CHOP or CHOP-like regimen. Further studies with larger samples are warranted to confirm our findings. 
Table 3 Univariate and multivariate analyses of the prognostic risk factors for overall survival in PTCL

\begin{tabular}{|c|c|c|c|c|}
\hline \multirow[t]{2}{*}{ Variable } & \multicolumn{2}{|c|}{ Univariate analysis } & \multicolumn{2}{|c|}{ Multivariate analysis } \\
\hline & HR (95\% Cl) & $P$-value & HR (95\% Cl) & $P$-value \\
\hline ECOG (0-I vs $2-4)$ & $\mathrm{I} .84(0.25-3.56)$ & 0.031 & $1.38(0.82-3.15)$ & 0.635 \\
\hline Ann Arbor stage (I-II vs III-IV) & $1.24(1.35-4.67)$ & 0.134 & & \\
\hline B symptoms (absent vs present) & $2.57(0.45-7.89)$ & 0.032 & $0.82(0.34-2.18)$ & 0.514 \\
\hline$\beta 2-M G$ (normal vs elevated) & $0.73(0.46-3.24)$ & 0.572 & & \\
\hline LDH (normal vs elevated) & $0.59(0.14-2.31)$ & 0.786 & & \\
\hline IPI (I-2 vs 3-5) & $4.12(1.59-6.45)$ & 0.028 & $4.12(1.36-6.72)$ & 0.01 \\
\hline $\mathrm{CCl}(0-\mathrm{I}$ vs $\geq 2)$ & $3.24(0.73-6.45)$ & 0.019 & $3.56(0.82-4.5 \mathrm{I})$ & 0.006 \\
\hline Therapeutic evaluation (CR/PR vs SD/PD) & $2.38(0.62-6.42)$ & 0.673 & & \\
\hline
\end{tabular}

Abbreviations: PTCL, peripheral T-cell lymphoma; HR, hazard ratio; $\mathrm{Cl}$, confidence interval; ECOG, Eastern Cooperative Oncology Group; $\beta 2-\mathrm{MG}, \beta$-microglobulin; LDH, lactate dehydrogenase; IPI, International Prognostic Index; CR, complete remission; PR, partial remission; SD, stable disease; PD, progressive disease; CCI, Charlson Comorbidity Index Score.

Table 4 Univariate and multivariate analyses of the prognostic risk factors for progression-free survival in PTCL

\begin{tabular}{|c|c|c|c|c|}
\hline \multirow[t]{2}{*}{ Variable } & \multicolumn{2}{|c|}{ Univariate analysis } & \multicolumn{2}{|c|}{ Multivariate analysis } \\
\hline & HR (95\% Cl) & $P$-value & HR (95\% Cl) & $P$-value \\
\hline ECOG (0-I vs 2-4) & $1.32(1.02-4.32)$ & $0.07 I$ & & \\
\hline Ann Arbor stage (I-II vs III-IV) & $1.48(0.58-3.64)$ & 0.233 & & \\
\hline B symptoms (absent vs present) & $2.72(1.63-6.42)$ & 0.045 & I.46 (0.68-2.89) & 0.472 \\
\hline$\beta 2-M G$ (normal vs elevated) & $1.29(0.7 \mathrm{I}-3.87)$ & 0.592 & & \\
\hline LDH (normal vs elevated) & $0.78(0.43-3.20)$ & 0.134 & & \\
\hline IPI (I-2 vs 3-5) & $2.94(I .52-5.6 I)$ & 0.032 & $3.01(0.98-5.61)$ & 0.017 \\
\hline $\mathrm{CCl}(0-\mathrm{I}$ vs $\geq 2)$ & $2.39(0.54-3.72)$ & 0.016 & $2.99(1.14-4.58)$ & 0.008 \\
\hline Therapeutic evaluation (CR/PR vs SD/PD) & $2.69(0.35-6.27)$ & 0.187 & & \\
\hline
\end{tabular}

Abbreviations: PTCL, peripheral T-cell lymphoma; HR, hazard ratio; $\mathrm{Cl}$, confidence interval; ECOG, Eastern Cooperative Oncology Group; $\beta 2$-MG, $\beta$-microglobulin; LDH, lactate dehydrogenase; IPI, International Prognostic Index; CR, complete remission; PR, partial remission; SD, stable disease; PD, progressive disease; CCI, Charlson Comorbidity Index Score.

A

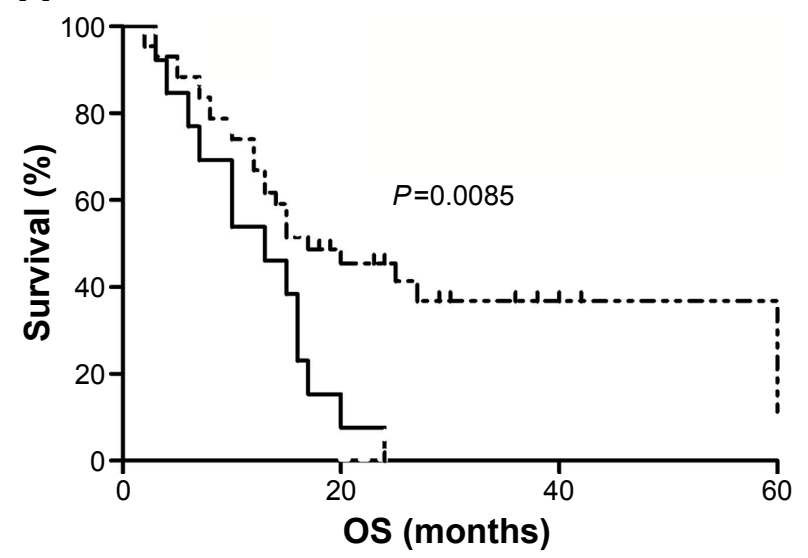

B

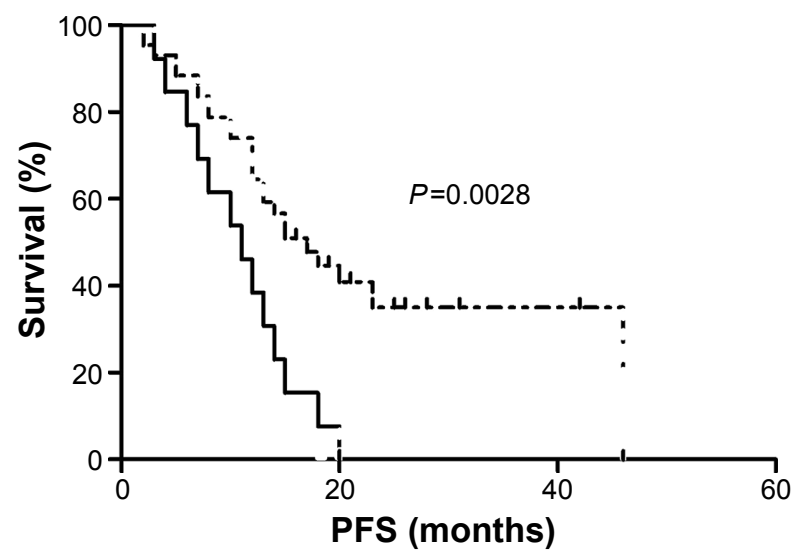

Figure I Ability of the Charlson Comorbidity Index $(\mathrm{CCI})$ score to predict overall survival $(\mathrm{OS})$ and progression-free survival (PFS) of elderly patients with peripheral T-cell lymphoma.

Notes: Both OS (A) and PFS $(\mathbf{B})$ in the high $\mathrm{CCl}$ group were significantly shorter than those in the low $C C l$ group $(P=0.0085$ and $P=0.0028$, respectively). 


\section{Acknowledgments}

This work was supported by grants from the National Natural Science Foundation of China (30672208 and 81270603) and the Tianjin Natural Science Foundation of China (13JCYBJC22800).

\section{Disclosure}

The authors report no conflicts of interest in this work.

\section{References}

1. Foss FM, Zinzani PL, Vose JM, Gascoyne RD, Rosen ST, Tobinai K. Peripheral T-cell lymphoma. Blood. 2011;117(25):6756-6767.

2. Vose J, Armitage J, Weisenburger D, International TCLP. International peripheral T-cell and natural killer/T-cell lymphoma study: pathology findings and clinical outcomes. J Clin Oncol. 2008;26(25): 4124-4130.

3. Hall SF. A user's guide to selecting a comorbidity index for clinical research. J Clin Epidemiol. 2006;59(8):849-855.

4. Yancik R, Ershler W, Satariano W, Hazzard W, Cohen HJ, Ferrucci L. Report of the National Institute on Aging Task Force on Comorbidity. J Gerontol A Biol Sci Med Sci. 2007;62(3):275-280.

5. de Groot V, Beckerman H, Lankhorst GJ, Bouter LM. How to measure comorbidity: a critical review of available methods. J Clin Epidemiol. 2003;56(3):221-229.

6. Lash TL, Mor V, Wieland D, Ferrucci L, Satariano W, Silliman RA. Methodology, design, and analytic techniques to address measurement of comorbid disease. J Gerontol A Biol Sci Med Sci. 2007;62(3): 281-285.

7. Schneeweiss S, Maclure M. Use of comorbidity scores for control of confounding in studies using administrative databases. Int J Epidemiol. 2000; 29(5):891-898.

8. Charlson ME, Pompei P, Ales KL, MacKenzie CR. A new method of classifying prognostic comorbidity in longitudinal studies: development and validation. J Chronic Dis. 1987;40(5):373-383.

9. Singh B, Bhaya M, Stern J, et al. Validation of the Charlson comorbidity index in patients with head and neck cancer: a multi-institutional study. Laryngoscope. 1997;107(11 Pt 1):1469-1475.

10. Ouellette JR, Small DG, Termuhlen PM. Evaluation of CharlsonAge Comorbidity Index as predictor of morbidity and mortality in patients with colorectal carcinoma. J Gastrointest Surg. 2004;8(8): 1061-1067.

11. Guzzo TJ, Dluzniewski P, Orosco R, Platz EA, Partin AW, Han M. Prediction of mortality after radical prostatectomy by Charlson comorbidity index. Urology. 2010;76(3):553-557.
12. Lin TL, Kuo MC, Shih LY, et al. The impact of age, Charlson comorbidity index, and performance status on treatment of elderly patients with diffuse large B cell lymphoma. Ann Hematol. 2012;91(9):1383-1391.

13. Kobayashi Y, Miura K, Hojo A, et al. Charlson Comorbidity Index is an independent prognostic factor among elderly patients with diffuse large B-cell lymphoma. J Cancer Res Clin Oncol. 2011;137(7): $1079-1084$

14. Thieblemont C, Grossoeuvre A, Houot R, et al. Non-Hodgkin's lymphoma in very elderly patients over 80 years. A descriptive analysis of clinical presentation and outcome. Ann Oncol. 2008;19(4):774-779.

15. Tomonaga M. [Outline and direction of revised WHO classification of Tumors of Haematopoietic and Lymphoid Tissues]. Rinsho Ketsueki. 2009;50(10):1401-1406. Japanese.

16. Cheson BD, Pfistner B, Juweid ME, et al. Revised response criteria for malignant lymphoma. J Clin Oncol. 2007;25(5):579-586.

17. Charlson M, Szatrowski TP, Peterson J, Gold J. Validation of a combined comorbidity index. J Clin Epidemiol. 1994;47(11):1245-1251.

18. O’Leary H, Savage KJ. The spectrum of peripheral T-cell lymphomas. Curr Opin Hematol. 2009;16(4):292-298.

19. Kim K, Kim WS, Jung CW, et al. Clinical features of peripheral T-cell lymphomas in 78 patients diagnosed according to the Revised European-American Lymphoma (REAL) classification. Eur J Cancer. 2002;38(1):75-81.

20. Ko OB, Lee DH, Kim SW, et al. Clinicopathologic characteristics of T-cell non-Hodgkin's lymphoma: a single institution experience. Korean J Intern Med. 2009;24(2):128-134.

21. Birim O, Kappetein AP, Goorden T, van Klaveren RJ, Bogers AJ. Proper treatment selection may improve survival in patients with clinical early-stage nonsmall cell lung cancer. Ann Thorac Surg. 2005;80(3):1021-1026.

22. Janssen-Heijnen ML, Houterman S, Lemmens VE, Louwman MW, Maas HA, Coebergh JW. Prognostic impact of increasing age and co-morbidity in cancer patients: a population-based approach. Crit Rev Oncol Hematol. 2005;55(3):231-240.

23. Read WL, Tierney RM, Page NC, et al. Differential prognostic impact of comorbidity. J Clin Oncol. 2004;22(15):3099-3103.

24. Janssen-Heijnen ML, van Spronsen DJ, Lemmens VE, Houterman S, Verheij KD, Coebergh JW. A population-based study of severity of comorbidity among patients with non-Hodgkin's lymphoma: prognostic impact independent of International Prognostic Index. Br J Haematol. 2005;129(5):597-606.

25. Wildes TM, Augustin KM, Sempek D, et al. Comorbidities, not age, impact outcomes in autologous stem cell transplant for relapsed non-Hodgkin lymphoma. Biol Blood Marrow Transpl. 2008;14(7): $840-846$.
OncoTargets and Therapy

\section{Publish your work in this journal}

OncoTargets and Therapy is an international, peer-reviewed, open access journal focusing on the pathological basis of all cancers, potential targets for therapy and treatment protocols employed to improve the management of cancer patients. The journal also focuses on the impact of management programs and new therapeutic agents and protocols on

\section{Dovepress}

patient perspectives such as quality of life, adherence and satisfaction. The manuscript management system is completely online and includes a very quick and fair peer-review system, which is all easy to use. Visit http://www.dovepress.com/testimonials.php to read real quotes from published authors. 